\title{
Climate Change, Carbon Tax, and the Indonesian Directorate General of Taxes Preparedness in Implementing the New Carbon Tax
}

\author{
Ryan Nugraha ${ }^{1}$, Paul Bologun ${ }^{2}$ \\ Institut Ilmu Sosial dan Manajemen STIAMI, Indonesia ${ }^{1}$ \\ Nigeria $^{2}$ \\ Correspondent: ryand.nugraha@gmail.com ${ }^{1}$
}

\author{
Received : August 26, 2021 \\ Accepted : January 15, 2022 \\ Published : January 31, 2022
}

Citation: Nugraha, R., Bologun, P (2022). Climate Change, Carbon Tax, and the Indonesian Directorate General of Taxes Preparedness in Implementing the New Carbon Tax. Ilomata International Journal of Tax \& Accounting.3(1), 35-45.

https://doi.org/10.52728/ijtc.v4i1.420

\begin{abstract}
One of the crucial issues in Indonesia is climate change. It can jeopardize Indonesia's sustainable development. This article investigates a carbon tax as a climate policy option in Indonesia and the Directorate General of Taxes readiness in imposing the new carbon tax bill in April 2022. This research analyzes the early stage of carbon tax implementation in Indonesia. The author conducted a qualitative questionnaire to a small and unrepresentative sample of 32 tax officers in the DGT's head office, regional office, and small tax office in Jakarta. The data collecting process took place in January 2022. The results suggest that most DGT's employees in this study are already familiar with the term "climate change", its causes, and its effects as a worldwide global catastrophe. Furthermore, most respondents understand what a carbon tax is but in terms of preparedness to implement the new carbon tax, only 21 of 32 employees (65.6 percent) believe Indonesia is prepared to impose the new tax. At the same time, 11 employees doubt the implementation due to lack of human resources, derived rules, and regulation dissemination.
\end{abstract}

Keywords: Carbon tax, tax, climate change, Indonesia.

\section{INTRODUCTION}

Indonesia's geographic positioning makes it highly vulnerable to climate change. As the largest archipelagic country consists of 17,508 islands straddling the equator, its archipelago is at a crossroads between two oceans, the Pacific and the Indian Ocean, and bridges two continents, Australia and Asia. From 1981-2018, Indonesia experienced a trend of rising temperature around $0.03{ }^{\circ} \mathrm{C}$ per year (Selvi et al., 2020). While from 2010-2018, greenhouse gas emissions (GHG) nationally experienced an upward trend of about 4.3 percent per year lead to an increased sea level of 0.8-1.2 cm/year, while about 65 percent of the population lives in coastal areas (Ministry of Finance Republic Indonesia, 2021). Rising sea surface temperatures are causing the extinction of coral reefs, seaweed, mangroves, some biodiversity and marine ecosystems (Ratnawati, 2016). It also raises the levels of severe floods and droughts that will exacerbate the scarcity of clean water. According to the NDC (2016), climate change can increase disaster risk hydrometeorology, which reaches 80 percent of the total disaster in Indonesia (Ministry of Environment and Forestry of 
Climate Change, Carbon Tax, and the Indonesian Directorate General of Taxes Preparedness in Implementing the New Carbon Tax

Nugraha and Bologun

Indonesia, 2016). Overall, potential economic loss Indonesia can achieve 0.66 percent to 3.45 percent of GDP by 2030 (Ministry of Environment and Forestry of Indonesia, 2020). Thus, Indonesia needs to prioritize climate issues and introduce its carbon tax policy to restrain energy sector emission growth, including shifting to develop lower-carbon energy markets and improving energy efficiency policy.

Therefore, through the Directorate General of Taxes (DGT), the government has been enacting policies to decrease the growth of greenhouse gas emissions from the energy sector, including transitioning to lower-carbon energy markets (Septiani et al., 2017). On October 7th, 2021, Indonesia passed a carbon tax of IDR30 (USD0.002) per kilogram of CO2 equivalent (CO2e) or USD2.13 per ton of $\mathrm{CO}_{2}$ emission above the stipulated cap under the Law No. 7 the Year 2021 on the Harmonization of Tax Regulations (UU HPP) (Simatupang et al., 2021). The carbon tax itself is based on a cap and tax system, which puts a fee on carbon emissions that exceed a predetermined cap . Beginning in April 2022, the Directorate General of Taxes intends to trial the coal-fired power generation industry tax. While In 2025, Indonesia wants to develop a carbon trading market and broaden the carbon tax to industries other than coal-fired power generating to reduce more $\mathrm{CO}_{2}$ emissions.

However, most Indonesians, including DGT's employees themselves, may be unaware of climate change and its carbon tax implications. Climate change is not a significant concern in this developing economy (Dinesh et al., 2021; Nugroho, 2020). The majority of public debates in Indonesia are centered on economic development and poverty eradication. According to a study conducted by Bohensky (2013), 81.9 percent of interviewed families in Indonesia are concerned about climate change. Nonetheless, reactive activities are taken in 38.9 percent of those individuals, while proactive steps are taken in 28.2 percent (Bohensky et al., 2013). These findings imply that the Indonesians has not correctly understood the idea of climate change. Thus, promoting adequate climate change information may be one way to enhance awareness about climate change in Indonesia (Selvi et al., 2020).

As the apparatus responsible for enacting the new carbon tax law, DGT's employee's growing environmental consciousness would affect public awareness. Therefore, it is critical to improving conversations and discourses regarding climate change and its effects on DGT's employees. As a consequence, it would strengthen the government's ability to enact policies aimed at reducing GHG emissions. This led us to our primary questions: How far is Indonesia's new carbon tax implementation? How do DGT employees perceive climate change? How is Indonesia's readiness, in this case, the DGT, in implementing the carbon tax?

The paper applies two qualitative analyses. First, we identify the early stage implementation in Indonesia's carbon tax policy (Ratnawati, 2016). The article also discusses carbon policy reforms applied in Japan. This is because Japan is the first country in Asia to run the carbon tax law and make carbon emissions reduction a state's priority (Fairbrother et al., 2019; McLaughlin et al., 2019). In the second part, the author discovers DGT employee's perspectives of climate change and their preparedness to implement the new law in April 2022. 
Climate Change, Carbon Tax, and the Indonesian Directorate General of Taxes Preparedness in Implementing the New Carbon Tax

Nugraha and Bologun

The author administers a qualitative questionnaire to a small and unrepresentative sample of 32 tax officers in the DGT's head office, regional office, and small tax office in Jakarta. The data collecting process took place on January 5th, 2022. The paper concludes that Indonesia needs to accelerate climate change and carbon tax awareness in the DGT's employee to promote the new policy.

Indonesia passed a carbon tax on October 7th, 2021, at a rate of IDR30 (USD0.002) per kilogram of CO2 equivalent (CO2e) similar to USD2.13 per ton of CO2e emission above the threshold cap. Law No. 7 of the Year 2021 on Tax Harmonization (UU HPP) revised numerous existing tax statutes and established the new carbon tax. For the first time, Indonesia has put a price on carbon emissions, following the lead of 26 other nations. This plan is part of Indonesia's larger strategy to fulfill its 2030 aim of reducing carbon dioxide (CO2) emissions by 29 percent on its own or 41 percent with international support (Saputra, 2021; Simatupang et al., 2021).

The goal of the new carbon tax is to reduce greenhouse gas emissions from production processes and individual consumption systematically and sustainably. The policy may also cause changes in behavior toward fossil fuels and encourage the use of renewable energy and also rise government revenue. Individuals and entities who purchase carbon-containing goods and engage in carbonemitting activities will face a tax. The carbon tax rate is set to be higher than or equal to the market price, with a minimum rate of IDR 30 (USD0.002) per kilogram of CO2 equivalent (CO2e). This rate is equivalent to USD2.13 per ton of CO2e emission (cap and tax). CO2e is a symbol for greenhouse gas emissions, including $\mathrm{CO} 2$, methane $(\mathrm{CH} 4)$, and nitrous oxide $(\mathrm{N} 2 \mathrm{O})$ (Simatupang et al., 2021).

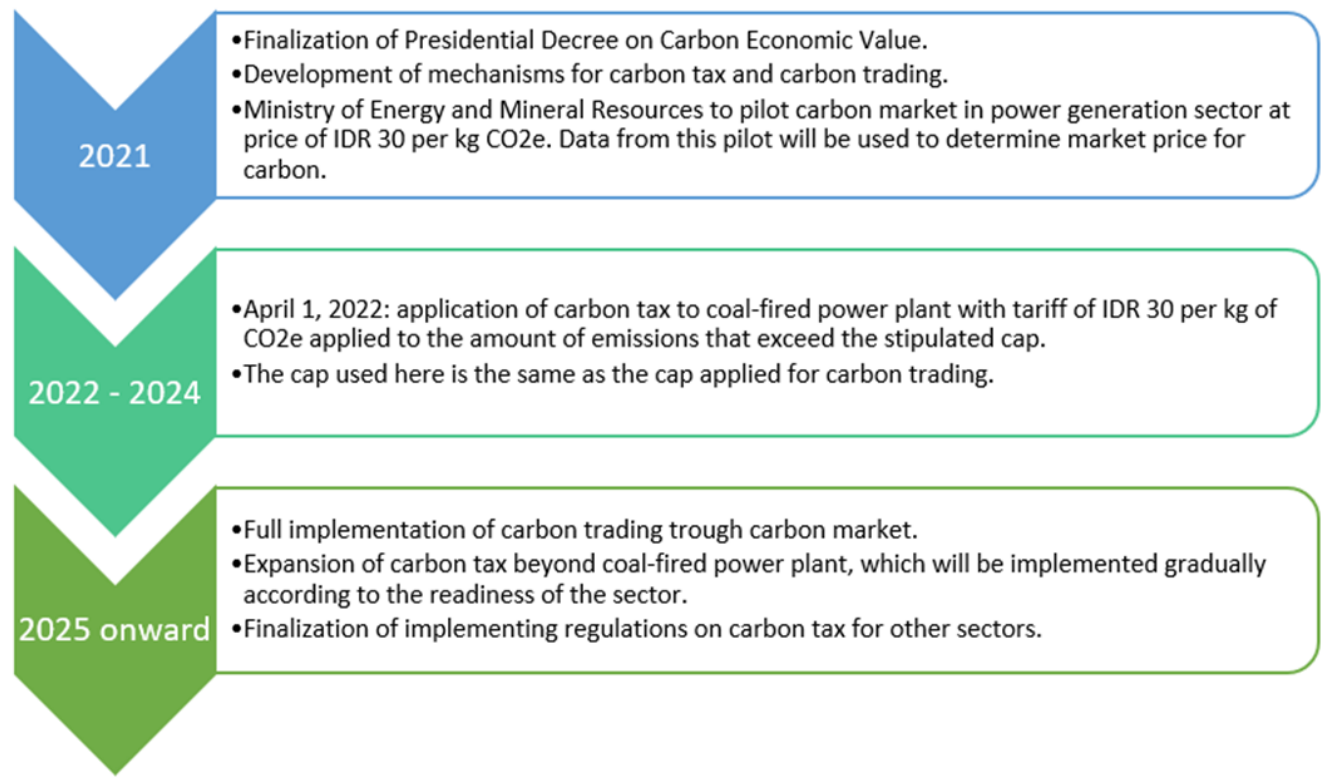

Figure 1 Indonesia Carbon Policy Road Map

Source: Simatupang, et.al. (2021)

The revenue generated by the carbon tax can be used to fund climate change campaign. Furthermore, individuals and corporates who participate in carbon emission trading governed by environmental law may be eligible for a carbon tax deduction on their carbon tax liability. The government will 
Climate Change, Carbon Tax, and the Indonesian Directorate General of Taxes Preparedness in Implementing the New Carbon Tax

Nugraha and Bologun

implement the carbon tax under the Roadmap for Carbon Tax, which the House of Representatives approved (Ministry of Energy and Mineral Resources of Indonesia, 2021).

However, according to Simatupang (2021), the new carbon tax could affect electricity affordability, jeopardizing Indonesia's goal of ensuring universal energy access by 2030. The potential uptrend in electricity prices would be detrimental to low-income households, many of which are considered energy poor. Because electricity costs account for up to 80 percent of production costs in some industries, rising electricity costs due to the carbon tax would raise consumer prices and make products less competitive.

\begin{tabular}{|l|l|l|}
\hline Institution & Tax rate per ton CO2e & Estimated revenue \\
\hline The World Bank and IMF & US\$ 30-100 & $\begin{array}{l}1.5 \% \text { of Gross Domestic Product } \\
\text { (GDP) }\end{array}$ \\
\hline $\begin{array}{l}\text { Bahana Sekuritas (an Indonesian } \\
\text { security company) }\end{array}$ & US\$ 5-10 & $\begin{array}{l}0.2 \%-0.3 \% \text { of GDP (US\$ 2-4.05 } \\
\text { billion) }\end{array}$ \\
\hline $\begin{array}{l}\text { Indonesian Taxation Analysis (an } \\
\text { Indonesian think tank) }\end{array}$ & US\$ 2.13 & US\$ 462 million \\
\hline
\end{tabular}

Figure 2 Indonesia Carbon Policy Road Map

Source: Simatupang, et.al. (2021)

The IMF and World Bank recommend a carbon tax rate of USD30 up to USD100 per ton CO2e for developing countries, resulting in a revenue of 1.5 percent of GDP. In this respect, the Indonesian Taxation Analysis (CITA) estimated that the power plant sector alone could generate IDR 6.5 trillion (US\$ 462 million). Currently, Indonesia's carbon tax rate of IDR30 per kg CO2e (USD2.13 per ton CO2e) is one of the lowest in the world. Bahana Sekuritas (an Indonesian security firm) predicted potential income of IDR 29 trillion - 57 trillion (US $\$ 2.0$ billion -4.05 billion), equivalent to $0.2-0.3$ percent of GDP, if tax rates are set at US\$ 5-10 per ton CO2e and applied to 60 percent of emissions (Simatupang et al., 2021).

Japan is a vital partner for Indonesia. Despite various global challenges, such as the Covid-19 pandemic, relations between Indonesia and Japan remain strong, and there is still room for strengthening ties that can be explored. In 2020, the bilateral trade value between Indonesia and Japan will be USD 24.3 billion. Japan consistently ranks third as Indonesia's leading export destination from 2018 to 2020, with export values reaching USD 13.6 billion in 2020. This trend is expected to continue, with the value of Indonesian exports to Japan reaching USD7.9 billion in semester $1-2021$.

In terms of investment, Japan's Foreign Investment (PMA) in Indonesia reached 12.9 billion USD from 2018 to Semester I - 2021. During that time, Japan surpassed the United States as the thirdlargest foreign investor in Indonesia. Meanwhile, the total number of PMA projects from Japan during that period exceeded 19 thousand. FDI from Japan into Indonesia has reached USD 1.04 billion until the first half of 2021. The Indonesian government hopes that foreign direct investment from Japan entering in 2021 will exceed the 2.6 billion USD realized in 20202021 (Ministry of Communication and Information Technology, 2021). This fact demonstrates that Indonesia remains appealing to foreign investors, including Japan. 
Climate Change, Carbon Tax, and the Indonesian Directorate General of Taxes Preparedness in Implementing the New Carbon Tax

Nugraha and Bologun

Japan is a country with limited energy resources. The government is highly reliant on imported energy to cover its energy needs based on Agency for Natural resources and energy. Japan is the world's fifth-largest oil consumer and fourth-largest crude oil importer (US Energy Information (U.S. Energy Information Administration, 2020). It is also the world's largest importer of liquefied natural gas and the third-largest coal importer. Japan's low carbon policy mix includes a carbon tax (integrated through an energy tax), two regional emission trading systems, the Tokyo Emission Trading System and the Saitama Emission Trading System (Kojima \& Asakawa, 2021), and a voluntary emissions trading scheme based on subsidies, namely the "Advanced Technologies Promotion Subsidy Scheme with Emission Reduction Targets” (ASSET).”

Currently, there are two environmental taxes in Japan: the vehicle tax and the energy tax: Japan's carbon tax, called the "Tax on Climate Change Mitigation" falls within the category of energy taxes (Gokhale, 2021). Moreover, Japan has a three-tiered energy tax (1) Customs duties on imported and extracted fossil fuels; (2) Transportation fuel taxes (Oil delivery tax, Gasoline tax, Diesel and Aviation Fuel tax); (3) Electric power generation taxes (Ministry of The Environment of Japan, 2017).

The carbon tax in Japan applies to fossil fuels such as petroleum, petroleum products, natural gas, and coal. Japan became the first Asian country to introduce a carbon tax of JPY 2,89/t-Co2 (YSD2.65) in October 2012 (Ministry of The Environment of Japan, 2017). By 2050, the tax intends to eliminate 80 percent of Japan's greenhouse gas emissions. Carbon taxes on covered items vary according to their carbon emissions content and are in addition to the existing petroleum and coal taxes. The tax rate is a fixed per-unit amount so that the total carbon tax on each product equals JPY 2,89/t-Co2 (USD2.65) (Gokhale, 2021).

Japan has made significant progress in decreasing its carbon emissions since the carbon tax was implemented in 2012. However, Japan's existing carbon tax policy impedes solving the urgent climate problem. A study from (Kawakatsu et al., 2017) found that a small or positive financial benefit is possible with appropriate tax revenue treatment. Kawakatsu et al. analyzed East Asia's low carbon policies. They concluded that Japan's current carbon tax rate of JPY2,89/t-Co2 (\$2.65) has resulted in modest emissions reductions and had a negligible influence on its economic growth. When evaluating a more significant carbon tax, the authors believe that a higher tax combined with suitable revenue recycling methods results in a positive double dividend for the Japanese economy (Lee et al., 2012). Japan's experience can be applied in Indonesia as a best practice in implementing carbon tax in 2022 , especially in the government readiness.

\section{METHOD}

The author utilizes a constructivism approach to qualitative data analysis in this study. The essence of constructivism is an understanding formed from several perspectives that solve a problem (Bungin, 2017). The answers to all situations being studied are sourced from various social perspectives or points of view. In this understanding, the researcher is tasked with narrowing down different comprehensive perspectives and interpreting the findings according to their experience and expertise (Creswell, 2017). 
Climate Change, Carbon Tax, and the Indonesian Directorate General of Taxes Preparedness in Implementing the New Carbon Tax

Nugraha and Bologun

The author examined three DGT positions: account representative, tax auditor, and staff analyst. The questionnaires were completed by 32 participants in January 2022. Each question is composed of five open-ended questions and five closed-ended question. The sample size is determined by the research design. Typically, the sample size for qualitative methods is between twenty and thirty people.

\begin{tabular}{lll}
\hline Position & Number Respondents & Percentage \\
\hline Account Representative & 5 & $15.6 \%$ \\
\hline Tax Auditor & 17 & $53.1 \%$ \\
\hline Staff Analyst & 10 & $31.3 \%$ \\
\hline
\end{tabular}

In addition, Cohen et al. (2017) argued that when using purposive sampling, it is more important to obtain information from those with extensive knowledge of a particular subject and to achieve data saturation than it is to maximize the number of participants (Cohen et al., 2017). Participants are chosen on the basis of their knowledge, expertise, and experience within their respective organizations and fields (Jamali, 2018). The respondents come from a variety of job descriptions and involved in the carbon tax's implementation process.

The open questions are intended to give employees the freedom to express their opinions and responses to the questions. Meanwhile, closed questions are used to confirm previous questions, allowing for the verification of the questionnaire response's consistency. The questionnaires contain five pairs of questions. Employees are asked to respond "yes" or "no" to closed questions, whereas open questions require employees to respond with some explanations, reasons, and opinions.

Consistency in responding to each pair of questions is measured in this study to ensure that employees provide accurate responses. Employees provide consistent responses when they respond "yes" to close questions, followed by a correct response to open questions. The correct responses are highlighted in this section if they contain certain keywords, such as global warming, deforestation, and changes in season pattern.

\section{RESULT AND DISCUSSION Climate Change: A General Overview}

When asked if the DGT employee's had ever heard of climate change and could explain what it is, 31 of 32 employees ( 97 per cent) responded that they had. Additionally, 27 of 31 employees provide consistent responses. The respondents who responded consistently used terms such as global warming, deforestation, greenhouse gases, and long-term climate variability. This means that the majority of DGT's employees in this study are already familiar with the term "climate change." Meanwhile, only one employee stated in this study that he or she was unfamiliar with the term "climate change." On the other hand, an employee who provides an inconsistent response to the first question primarily explains that climate change is a "transition from one state to another", "weather changes", or "temperature changes". They may have heard about climate change, but they were unable to provide accurate responses to the questions. 
Climate Change, Carbon Tax, and the Indonesian Directorate General of Taxes Preparedness in Implementing the New Carbon Tax

Nugraha and Bologun

\section{Climate Change's Primary Causes}

When asked about their knowledge of the primary causes of climate change and their ability to explain the primary causes of climate change, 28 of 32 (87.5 per cent) DGT employees stated that they were aware of the primary causes of climate change. However, only 21 employees ( 67 percent of the 87.5 percent) were able to consistently provide responses. This demonstrates that not all DGT employees are capable of accurately explaining the primary causes of climate change.

Employees who provide inconsistent responses to the fourth question primarily provide reversal responses by referring to climate change impacts as primary causes of climate change, such as "weather changes". Other reasons why employee give inconsistent responses to the second question in this study are incorrect responses, such as a "sea tidal wave", "a change in the earth's orbit", "a change in the atmosphere", and "a change in the amount of rain falling", "warmer earth", and "human and natural habits". As a result, there is misinformation about the causes and effects of climate change among the employees in this study. Additionally, 2 of 32 employees stated that they were unaware of the primary causes of climate change when responding to the third question.

\section{Climate Change as a worldwide global catastrophe}

Employee responses to the fifth and sixth questions about whether climate change is a global threat and why climate change is a global threat indicate that as many as 31 of 32 ( 97 percent) employees believe climate change is a global catastrophe, with a percentage of consistent responses of 64 percent. This shows that the majority of employees in this study believe climate change is a serious issue.

In this regard, employees who consistently respond positively to the fifth question believe that climate change can cause diseases, and also disasters, such as "sea-level rise", "flooding", "storms", "heat waves", "drought", "animal extinction", "food scarcity", "forest fires", "poor harvests", "rising temperatures", or "the melting of the North Pole". On the other hand, inconsistent responses to the fifth question provided at the sixth question are primarily the result of incorrect responses to the subsequent question of why climate change is considered as a global catastrophe. "Air pollution," "global warming," "temperature change," and "illegal logging" are among the responses. According to one respondent, "Earth is our only home." The other is unclear when the phrase "Ecosystem shifting on Earth" is used.

\section{The Carbon Tax}

Following that, the employee responses to the seventh question about whether the employee understands what a carbon tax is and the eighth question about whether the employee understands what a carbon tax is and if they are able to explain how the carbon tax works, 29 of 32 employees (90.6 percent) understand what it is. However, there are only 25 employees ( 86 percent) who consistently respond. Employees who consistently responded positively to the seventh question mentioned the carbon tax definition as "a tax imposed on carbon emissions that have a negative impact on the environment". Inconsistent responses to the eighth question, on the other hand, are generally the result of incorrect responses, such as "cap and tax mechanism," and a lengthy response that contradicts the sentence "Carbon tax is one strategy to limit climate change." And a response stated "Entrepreneur's behavior is projected to change as a result of the carbon price, causing them to shift to low-carbon, green economic activity." 
Climate Change, Carbon Tax, and the Indonesian Directorate General of Taxes Preparedness in Implementing the New Carbon Tax

Nugraha and Bologun

\section{The DGT's Preparedness to Implement the New Carbon Tax}

Finally, employee responses to the 9th question, "Do you believe Indonesia is prepared to impose a carbon tax in April 2022?" and the 10th question, "Can you describe how Indonesia is preparing to impose a new carbon tax in April 2022?" indicate that only 21 of 32 employees (65.6 percent) believe Indonesia is prepared to impose the tax, while 11 employees (34.4 percent) do not. Employees who consistently answer correctly to the ninth question are 20 officers. The majority of them cited a newly enacted "Carbon Tax law" as evidence of the DGT's readiness.

On the other hand, 11 employees who believe DGT is not prepared to implement the policy cited various reasons, including "the need for derived rules," "it is too early to prepare the human resource in DGT", "opposition and difficulties from vertical units that implement it", and "a lack of regulation dissemination." One respondent who responses DGT's preparedness stated,

"There are too many elements that affect the poorest members of society, who are indirectly impacted by price increases linked with the carbon tax, so there will definitely be additional benefits and drawbacks to consider. Furthermore, Indonesia has only recently recovered from the pandemic".

\section{CONCLUSION}

As a global environmental issue, climate change must be communicated to citizens. On the other hand, climate change may not be a significant issue for society in several countries worldwide, including Indonesia (Levi, 2021; Onyimadu \& Uche, 2021). When it comes to fighting climate change using carbon tax policy, the DGT's employees are responsible for enhancing public awareness (Costello, 2019). The author provides a qualitative analysis to understand awareness about climate change, carbon tax, and tax authority's readiness in enacting the new carbon tax law in April 2022. The paper also provides a best practice lesson in implementing a carbon tax in Japan.

The author found a slight lack of awareness about climate change among DGT employees, which may occur in other positions within the DGT on a national level. Nonetheless, the DGT has made some efforts to combat climate change, including establishing a carbon tax road map and preparing the derived rule .

Based on these conclusions, the researcher advises policymakers, namely DGT, to increase employee's awareness of climate change. First, we advise an increase of learning process through attendance at climate change courses that improve understanding of climate change. These environment courses are currently available through Massive Open Online Courses (MOOCs). Additionally, the DGT could enhance its digital learning program, Studia, by including climate change curricula.

Second, the DGT can promote media literacy. Media literacy can help increase public awareness and acceptance of climate change (Jürkenbeck et al., 2021; Phan et al., 2021). The DGT may organize an art festival, essay competition, and poster competition to raise awareness about climate change and the carbon tax. A study by Jacobson et al. (2016) proposes a climate change exhibition that combines art and science (Jacobson et al., 2016). 
Climate Change, Carbon Tax, and the Indonesian Directorate General of Taxes Preparedness in Implementing the New Carbon Tax

Nugraha and Bologun

Finally, the DGT may achieve a high level of support from citizens by using a prominent spokesperson to campaign for climate change awareness. An effective policy reform needs interministerial strategic cooperation, non-governmental organizations, and legislative members. The DGT should communicate continuously with these stakeholders.

The proposed policy incorporates the necessary precondition for resolving the issue. Yet, a wellexecuted implementation is critical to achieving a positive outcome.

\section{REFERENCE}

Bohensky, E. L., Smajgl, A., \& Brewer, T. (2013). Patterns in household-level engagement with climate change in Indonesia. Nature Climate Change, 3(4), 348-351. https://doi.org/10.1038/nclimate1762

Bungin, B. (2017). Metodologi Penelitian Kualitatif(B. Bungin (ed.); 3rd ed.). RajaGrafindo Persada. https://www.rajagrafindo.co.id/produk/metodologi-penelitian-kualitatif-burhan-bungin/

Cohen, L., Manion, L., \& Morrison, K. (2017). Research Methods in Education. In London: Routledge. (8th ed.). Routledge. https://doi.org/10.4324/9781315456539

Costello, K. W. (2019). Essay on climate apocalypse and a carbon tax. The Electricity Journal, 32(10), 106669. https://doi.org/10.1016/j.tej.2019.106669

Creswell, J. W. (2017). Research Design Pendekatan Kualitatif, Kuantitatif, dan Mixed (S. Z. Qudsy (ed.); 3rd ed.). Pustaka Pelajar. https://opac.perpusnas.go.id/DetailOpac.aspx?id=1213690

Dinesh, D., Hegger, D. L. T., Klerkx, L., Vervoort, J., Campbell, B. M., \& Driessen, P. P. J. (2021). Enacting theories of change for food systems transformation under climate change. Global Food Security, 31, 100583. https://doi.org/10.1016/j.gfs.2021.100583

Fairbrother, M., Johansson Sevä, I., \& Kulin, J. (2019). Political trust and the relationship between climate change beliefs and support for fossil fuel taxes: Evidence from a survey of 23 European countries. Global Environmental Change, 59, 102003. https://doi.org/10.1016/j.gloenvcha.2019.102003

Gokhale, H. (2021). Japan's carbon tax policy: Limitations and policy suggestions. Current Research in Environmental Sustainability, 3, 100082. https://doi.org/10.1016/j.crsust.2021.100082

Jacobson, S. K., Seavey, J. R., \& Mueller, R. C. (2016). Integrated science and art education for creative climate change communication. Ecology and Society, 21(3), art30. https://doi.org/10.5751/ES-08626-210330

Jamali, H. R. (2018). Does research using qualitative methods (grounded theory, ethnography, and phenomenology) have more impact? Library \& Information Science Research, 40(3-4), 201207. https://doi.org/10.1016/j.lisr.2018.09.002

Jürkenbeck, K., Spiller, A., \& Schulze, M. (2021). Climate change awareness of the young generation and its impact on their diet. Cleaner and Responsible Consumption, 3, 100041. https://doi.org/10.1016/j.clrc.2021.100041

Kawakatsu, T., Lee, S., \& Rudolph, S. (2017). The Japanese Carbon Tax And The Challenges To LowCarbon Policy Cooperation In East Asia (No. 9; 17). https://ideas.repec.org/p/kue/epaper/e17-009.html

Kojima, S., \& Asakawa, K. (2021). Expectations for Carbon Pricing in Japan in the Global 
Climate Change, Carbon Tax, and the Indonesian Directorate General of Taxes Preparedness in Implementing the New Carbon Tax

Nugraha and Bologun

Climate Policy Context. In T. H. Arimura \& S. Matsumoto (Eds.), Economics, Law, and Institutions in Asia Pacific (1st ed., pp. 1-21). Springer International Publishing. https://doi.org/10.1007/978-981-15-6964-7_1

Lee, S., Pollitt, H., \& Ueta, K. (2012). An Assessment of Japanese Carbon Tax Reform Using the E3MG Econometric Model. The Scientific World Journal, 2012, 1-9. https://doi.org/10.1100/2012/835917

Levi, S. (2021). Why hate carbon taxes? Machine learning evidence on the roles of personal responsibility, trust, revenue recycling, and other factors across 23 European countries. Energy Research \& Social Science, 73, 101883. https://doi.org/10.1016/j.erss.2020.101883

McLaughlin, C., Elamer, A. A., Glen, T., AlHares, A., \& Gaber, H. R. (2019). Accounting society's acceptability of carbon taxes: Expectations and reality. Energy Policy, 131, 302-311. https://doi.org/10.1016/j.enpol.2019.05.008

Ministry of Energy and Mineral Resources of Indonesia. (2021). Energy Minister Explain Carbon Tax Scheme. https://www.esdm.go.id/en/media-center/news-archives/energy-ministerexplains-carbon-tax-schemes

Ministry of Environment and Forestry of Indonesia. (2016). 1 st Nationally Determined Contribution (NDC) Indonesia. http://ditjenppi.menlhk.go.id/reddplus/images/resources/ndc/First_NDC.pdf

Ministry of Environment and Forestry of Indonesia. (2020). Updated Nationally Determined Contribution (NDC).

https://www4.unfccc.int/sites/ndcstaging/PublishedDocuments/Indonesia First/Updated NDC Indonesia 2021 - corrected version.pdf

Ministry of Finance Republic Indonesia. (2021). Indonesia's Commitment on Climate Change Amidst the COVID-19 Pandemic.

https:// fiskal.kemenkeu.go.id/nda_gcf/en/publications/indonesia-s-commitment-onclimate-change-amidst-the-covid-19-pandemic

Ministry of The Environment of Japan. (2017). Greening of Whole Tax System and Carbon Tax in Japan. Environment and Economy Division. In Environment-related Tax in Japan. https://www.env.go.jp/en/policy/tax/20170130_greening.pdf

Nugroho, A. W. (2020). What students know about climate change? a case study of high school students in Samboja, Indonesia. IOP Conference Series: Earth and Environmental Science, 487(1), 012001. https://doi.org/10.1088/1755-1315/487/1/012001

Onyimadu, C. O., \& Uche, D. S. (2021). Evaluating the Nigerian Government's financial obligations to climate change adaptation strategies. Climate Services, 24, 100261. https://doi.org/10.1016/j.cliser.2021.100261

Phan, T. D., Bertone, E., Pham, T. D., \& Pham, T. V. (2021). Perceptions and willingness to pay for water management on a highly developed tourism island under climate change: A Bayesian network approach. Environmental Challenges, 5, 100333. https://doi.org/10.1016/j.envc.2021.100333

Ratnawati, D. (2016). Carbon Tax Sebagai Alternatif Kebijakan Untuk Mengatasi Eksternalitas Negatif Emisi Karbon di Indonesia. Indonesian Treasury Review Jurnal Perbendaharaan Kenangan Negara Dan Kebijakan Publik, 1(2), 53-67. https://doi.org/10.33105/itrev.v1i2.51

Saputra, A. I. (2021). Pajak Karbon Sebagai Sumber Penerimaan Negara dan Sistem Pemungutannya. Jurnal Anggaran Dan Keuangan Negara Indonesia (AKURASI), 3(1), 56-71. 
Climate Change, Carbon Tax, and the Indonesian Directorate General of Taxes Preparedness in Implementing the New Carbon Tax

Nugraha and Bologun

https://doi.org/10.33827/akurasi2021.vol3.iss1.art96

Selvi, Rahmi, N., \& Rachmatulloh, I. (2020). Urgensi Penerapan Pajak Karbon di Indonesia. Jurnal Reformasi Administrasi, 7(1), 29-34.

https://doi.org/https://doi.org/10.31334/reformasi.v7i1.845

Septiani, M., Istislam, \& Anshari, T. (2017). Urgensi Pengaturan Penetapan Pajak Karbon (Carbon Tax) Dalam Upaya Peningkatan Pengendalian Pencemaran Udara di Indonesia. Jurnal Hukum Universitas Brawijaya, 4(1), 1-13. http://hukum.studentjournal.ub.ac.id/index.php/hukum/article/view/2343

Simatupang, R., Pineda, J., \& Murdjijanto, T. (2021). On Indonesia's new carbon tax and its effectiveness at reducing greenhouse gas emissions. https://devtechsys.com/insights/2021/11/24/onindonesias-new-carbon-tax-and-its-effectiveness-at-reducing-greenhouse-gas-emissions/

U.S. Energy Information Administration. (2020). Country Analysis Executive Summary: Japan. In World Country Energy Analysis.

https://www.eia.gov/international/content/analysis/countries_long/Japan/japan.pdf 